\title{
The Development Strategy for Community Empowerment in the Framework of Fire Prevention and Control fires and Haze in Oil Palm in South Kalimantan
}

\author{
Yudi Ferrianta ${ }^{1}$, Mira Yulianti ${ }^{2}$, Hairi Firmansyah ${ }^{3}$, Muhammad Alif $^{4}$ \\ ${ }_{1,2,3}$ Department of Agribusiness , Faculty of Agriculture, Lambung Mangkurat University \\ ${ }^{4}$ Department of Communication Science, Faculty of Political and Social Sciences, Lambung Mangkurat
}

University

\begin{abstract}
Land and forest fire disasters occur every year. Such conditions lead to disaster smog that many negative impact on society. Limited access to information community, especially around the area of Coconut Plantation potentially cause many problems, such as reduced household income caused by smog, the highaffected community respiratory tract infections as well as conflict disharmony social relationships that exist in society. Mistakes in communicating an information, could lead to uncertainty which aggravated the situation. In this situation, communication and community empowerment approach is urgently needed, taking into account the circumstances and social change. This study aims to examine how socioeconomic conditions of communities around oil palm plantations and the extent of the role of community institutions in the activities of prevention and suppression of fires and haze, and determine the communication strategy of community empowerment in the prevention and suppression of fires and smoke haze oil palm plantations in South Kalimantan, Indonesia.

the results showed that the alternative chosen strategy is as follows: (a) Improving socialization, campaigns and the effectiveness of inter-institutional communication for the prevention of forest fires; optimization of the institutional role of Fire Response Group at the grassroots level and improve the knowledge and skills of the community in the management of land resources in order to prevent fires.
\end{abstract}

Keywords: Communication strategy, fires, palm oil plantations

\section{Introduction}

Industrial plantations and palm oil processing industry is key to the economy of Indonesia. In addition, the rapid growth of the palm oil industry in Indonesia, is now considered a serious threat to countries in Europe. That is because competition vegetable oil which is considered favorable crude palm oil, which is the flagship product from Indonesia and Malaysia.The condition is followed by the emergence of a variety of negative accusations against farmers / palm oil companies in Indonesia, on the issue of environmental damage to public lands conflicts associated with the opening of oil palm plantations. Even the content of the media today tend to accuse and raises the issue of the causes of forest fires is done by small farmers and industrial scale in the clearing process palm oil.

In the province of South Kalimantan, forest fire disasters occur every year. Such conditions lead to disaster smog that many negative impact on society. Based on preliminary studies researcher, in 2015 this is the worst smog disaster that occurred in South Kalimantan compared to previous years. Land fires not only caused by human error and negligence, but also influenced by natural conditions. Long droughts as a result of the El Nino resulted in conditions become dry land. In the region of South Kalimantan fires occur mostly in suboptimal land, not only in the peat areas, but also in the dry land and wetlands. Limited access to information community, especially around the area of Palm Oil in South Kalimantan region on the effects of fire and smoke is still sorely lacking. This could potentially lead to many problems, such as reduced household income caused by smog, the high-affected community respiratory tract infections as well as conflict disharmony social relationships that exist in society.

Preventive measures to overcome the problem of haze is less recognized by the relevant institutions. Either from the government or private companies and public institutions. Not connected it's all elements of society causing fires and haze condition is becoming increasingly worrying. Often the communication problem becomes a major factor in the acceptance of such information would be a disaster. Communication in a disaster is not only needed in emergency conditions, but also important at the time and the pre-disaster. Preparing communities in disaster-prone areas should certainly always done. In addition to adequate information about the potential for disaster in an area, training and internalize habits for disaster situations should also be done on an ongoing basis. But the concern is abundant information alone is not enough to sensitize the citizens on the dangers of impending disaster. 
Mistakes in communicating an information, could lead to uncertainty which aggravated the situation. In this situation, communication and community empowerment approach is urgently needed, taking into account the circumstances and social change. Therefore it is necessary to examine how socioeconomic conditions of communities around oil palm plantations and the extent of the role of community institutions in the activities of prevention and suppression of fires and haze, and determine the communication strategy of community empowerment in the prevention and suppression of fires and smoke haze plantations Palm oil Generally, this research aims to produce a communication strategy in the prevention community empowerment and disaster management sub-optimal land fires and haze in the area of oil palm plantations in South Kalimantan

\section{Methods}

The study was conducted in Barito Kuala and Tapin. The research activities carried out during the year.Where the design of the communication strategy of community empowerment in disaster prevention and mitigation of fires and haze in oil palm plantations. South Kalimantan with AHP (Analytical Hierarchy Process).

\section{Results And Discussion}

Based on the data and the fact that it has a team of researchers collected during the research activities carried out either through primary data collection through surveys and data collection through FGD (Focus Group Discussion) various levels of government and stakeholders obtained formulation communications strategy community empowerment in prevention and disaster mitigation fire land sub-optimal and haze area south Kalimantan oil palm plantation as follows: In the formulation of a communication strategy based on the Analytical Hierarchy Process There are three main actors involved in communication activities empowerment of communities in prevention and mitigation of catastrophic fires in sub-optimal land and smog in the area of oil palm plantations south Kalimantan, namely the public and community group members responsive fire, local government through the regional disaster management agencies and the security forces (Indonesian National Police and Indonesian National Armed Forces) who since 2015 was given additional duties in addition to maintaining security and order are also tasked to engage in disaster relief land and forest fires. In addition there are three actors to which the stakeholders can play a role as a key actor of the success of the whole program of work of the two main actors in forest fire management program and land in 2016.

$\begin{array}{ll}\text { Analytical Hierarchy Process } & \text { Results } \\ \text { Level 1: actor } & \\ \text { Alternative } & \text { Priority } \\ \text { Local Government } & , 311 \\ \text { Security forces } & , 196 \\ \text { Society } & , 493 \\ \text { Inconsistency }=0,05 & \end{array}$

With 0 missing judgment

Factors used in the preparation of the priority scale is considered to be factors that affect actors in determining the communication strategy of community empowerment in the prevention and mitigation of catastrophic fires in sub-optimal land and smog in the area of oil palm plantations in South Kalimantan, these factors include:

1. Characteristic elements of communication in society as the main feature of the characteristics of communication that had been done by community members who are focused on the sources of communication available, communication media used and owned by the community and effect given by the community to communicate.

2. The nature and characteristics of the physical environment as the existing natural environment around the residence community that if it can be a source and trigger of land and forest fires, some natural environmental conditions such as droughts, wet peat soil during the rainy season and very dry during the dry season as well as their agricultural waste such as rice straw are examples of some of the physical and natural environmental conditions that influence the occurrence of forest fires and land.

3. Conditions community institutions as the existence and condition of institutional community level in carrying out its functions and duties, especially since early in the process of communication with external agencies and internal communication among members of the institution that if it can be empowered in the context of prevention and control of forest and land fires.

4. Rules and Government Policy interpreted as the Government's commitment to enforcing that have been made in the form of law, government regulations and local regulations. As well as the commitment of the Government in implementing policies related to prevention and control of forest fires and land. 
Analytical Hierarchy Process Results

\section{Level 2: factor}

\section{Alternative}

Natural Conditions and Physical Environment

Rules and Government Policy

Institutional conditions in Society

Characteristic Elements of Communication

Inconsistency $=0,07$

With 0 missing judgment

Goals become priorities in implementing communication strategies in the prevention community empowerment and disaster management sub-optimal land fires and haze in the area of oil palm plantations south Kalimantan, among others:

1. Increased community participation through effective communication through existing institutions in the community in prevention and disaster management fires an effort to improve the achievement of a shared understanding of the message conveyed by a communicator with a communicant of various prevention and control forest fires and land wrong only by establishing and utilizing institutions-institutions that exist in society.

2. Reducing and eliminating hotspots as a source of catastrophic fires as the efforts made jointly by the people to abolish hotspots as a result of land and forest fires in their area so as to achieve zero hot spot.

3. Improving the welfare of communities in disaster prevention and control fires interpreted as an effort to increase public revenue by utilizing agricultural waste which is usually the source of agricultural fire into products that have high economic value so as to increase public revenue.

\section{Analytical Hierarchy Process Results}

\section{Level 3: objectives}

Alternative

Reducing and eliminating points of Fire

Increasing the effectiveness of communication agencies Improvement of Public Welfare

Inconsistency $=0,06$

With 0 missing judgment

In order to achieve these objectives, the strategy chosen alternatives are as follows:

1. Enhancing socialization and land fire prevention campaign is an effort to improve socialization and campaigns to the public about the causes, dangers and the importance of prevention fires persuasive manner so as not to place land and forest fires.

2. Improving the effectiveness of inter-institutional communication for the prevention of forest fires is an effort to improve the effectiveness of the communication process that occurs in the community resulting in understanding and perceptions about the prevention and control of forest and land fires.

3. Optimization of the institutional role of Fire Response Group at the grassroots level for prevention of forest fires efforts to optimize the role and functions of institutions Fire Response Group in the context of prevention and control of forest and land fires.

4. Enhancing the knowledge and skills of the community in the prevention of forest fires is an effort to provide the knowledge and skills of the public about the causes, dangers and how to prevent and combat forest fires and land.

5. Enhancing the knowledge and skills of the community in the management of land resources that are around them are efforts to increase knowledge and skills of the community in managing agricultural land for which they earned so as to minimize the fire hazard of agricultural land to farmers.

6. Community empowerment in efforts to use natural resources become a source of new economy is an attempt to mobilize the community to take advantage of natural resources which have been considered as waste and useless so that they can be output which has high economic value and is able to become a new source of revenue or reduce costs farming

\section{Analytical Hierarchy Process Results}

Level 4: Strategy

Synthesis with respect to:

\section{Alternative}

- Enhancing socialization and prevention campaigns fires

Priority

, 224

- Improving the effectiveness of inter-institutional communication for the prevention of forest fires

- Optimizing the institutional role at the grassroots level for prevention of forest fires ,174 
- Improving the knowledge and ability of people in fire prevention land

- Improving the knowledge and ability of people in the management of land Resources that are around them ,128

- Community empowerment in efforts to use natural resources become a source of new economy

- $\quad$ Overall inconsistency $=0,06$

\section{Forest Fire Prevention and Community Development and Land-Based Local Wisdom}

Based on the results of the Focus Group discussion, problems become major source of land and forest fires in South Kalimantan is waste rice plants such as rice straw left on farmland after the rice harvest is completed which usually coincides with the dry season, so the remnants of rice straw in farmer's land becomes flammable media and became conductor of spillover source of fire from one land to another land and forests to agricultural land and vice versa. Therefore, utilization of rice straw is a waste of former agricultural land harvest society (farmers) is one of the appropriate measures in order to empower the community to prevent and reduce the incidence of forest fires and land in the study area.

Lack of knowledge, skills and technology owned by the community in efforts to use waste rice straw are the factors that influence why people today do not or have not taken advantage straw waste into something useful and even able to make money as an extra income for the family and the community itself. This is further exacerbated by the habits of the people who think that burning waste rice straw in agricultural land during the dry season is one of the appropriate measures to facilitate the work on agricultural land in the next planting season and to eliminate a wide range of plant pests and diseases that attack plants their paddy season when the ground is not to attack again the next planting season. That is why our team of researchers and community considers the need for a breakthrough in changing the mindset (thought) communities to use straw waste to be utilized as handmade products such as handmade products as well as the utilization of waste straw into media oyster mushroom cultivation to bring rupiah and for society while reducing the occurrence of fires resulting from the burning of agricultural land for hay clearance of agricultural land owned by farmers.

\section{Conclusion:}

\section{Conclusions And Recommendations}

1. Based on the Analytic Hierarchy Process (AHP) there are three main actors involved in communication activities Empowering communities in the prevention and disaster management sub-optimal land fires and haze in the area of oil palm plantations in South Kalimantan, namely the public and community members fire response group, the Local Government through Regional Disaster Management Agency and also the security forces.

2. F actor-factor used in the preparation of the priority scale is considered to be factors that affect actors in determining the strategy include: (1) Characteristics of communication elements (2) The condition of natural and physical environment, (3) Condition community institutions and (4) rules and Government Policy

3. Goals become priorities, among others: (a) Increasing community participation through effective communication through existing institutions in the community in prevention and disaster management fires (2) reducing and eliminating hotspots as a source of catastrophic fires and (3) Increased public welfare

4. A alternative chosen strategy are as follows:

a. Enhancing socialization and prevention campaign fires.

b. Improving the effectiveness of inter-institutional communication in order to $\mathrm{p}$ Flood protection forest fires

c. Optimization of the institutional role of Fire Response Group at the grassroots level

d. Improving the ability of knowledge and skills of the community in the prevention of fires and

e. Improving the ability of community knowledge and skills in the management of land resources that are around them

5. Designing a communication strategy include: audience strategy, message strategy, media strategy, and strategic communicator.

\section{Recommendation:}

Disaster prevention and mitigation of fires and haze in the area of oil palm plantations in South Kalimantan is by utilizing the natural resources around what would be the main source of the cause of fires through a process of community empowerment.

\section{Acknowledgement}

This study is funded by Fund Management Agency of Oil Palm Plantation Indonesia (Badan Pengelola Dana Perkebunan Kelapa Sawit - BPDPKS). The authors gratefully acknowledge the critical and thoughtful comments of reviewers, which has improved the manuscripts substantially. 


\section{References}

[1] Agus F, Subiksa IGM. 2008. Peat land: The potential for agriculture and environmental aspects. Soil Research Institute and World Agroforestry Centre (ICRAF).

[2] Akbar A. 2008. Community-based Forest Fire Control as a Fighting Risks in REDD. Techno Forest Plant 1 (1): 11-22.

[3] Anthony RN, Govindarajan V. 1992. Management Control System, Edition 8th. Homewood, Illinois (US): Richard D. Irwin Inc.

[4] Arip MA, LS Yee, TS Feng. 2013. Assessing the Competitiveness of Malaysia and Indonesia Palm Oil Related Industry. Journal World Review of Business Research Vol. 3. No. 4. November 2013.

[5] Boer, R, Kolopaking L, Bagja B, and Dasanto BD, 2007. Early Warning Systems in Indonesia for flood, forest fire, volcano eruption and tsunami. Final Report to GTZ, Jakarta.

[6] Chandler C, Cheney P., Thomas P.,Trabaud L., Williams D. 1983. Fire In Forestry Vol I: Forest Fire Behavior and Effects. John Wiley and Sons: Canada.

[7] Debano LF, Neary DG, Ffolliot PF. 1998. Fire's Effect on Ecosystems. John Wiley and Sons, Inc. New York (USA)

[8] De Leon JCV. 2009. Community early warning systems: A strategy for the local management of disaster reduction in Central America.

[9] Deeming JE. 1995. Development of a Fire Danger Rating System for East Kalimantan, Indonesia. Integrated Forest Fire Management Project, Samarinda. German Agency for Technical Cooperation and the Ministry of Forestry. Jakarta. Indonesia

[10] Ferrance E. 2000. Action Research. LAB Northeast and Islands Regional Educational Laboratory at Brown University.

[11] Goldammer JG, Brady M, Csiszar IA, de Groot WJ, Justice CO, Keenan T, Lorentz E, O’Loughlin K, Lynham TJ, Oertel D, Stock BJ. 2006. Development of a Global Wild land Fire Early Warning System within the envisaged Multi-Hazard Global Early Warning System. Presentation Paper, Third International Early Warning Conference Scientific and Technical Symposium. Bonn, Germany, 28 March 2006

[12] Hazimah AH. 2012. Palm Oil: Going Beyond Basic Chemical. Palm Oil Trade Fair Seminar Dusit Thani Hotel, Manila.

[13] Hax AC, Majluf, NS. 1984. Strategic Management An Integrative Perspective. Englewood Cliffs (UK): Prentice-Hall Inc.

[14] Hecker JH. 2005. Promoting Environmental Security and Poverty Alleviation in the Peat Swamps of Central Kalimantan, Indonesia Commissioned by the Institute for Environmental Security, The Netherlands.

[15] Hunger JD, Wheelen TL. 2003. Strategic Management, Edition 5. Addison-Wesley Publishing Company Inc.

[16] Hwang CL, K Yoon. 1981. Multiple Attribute Decision Making Methods and Applications. Berlin (DE): Springer.

[17] Jiwan N. 2009. Political Economy Of The Indonesian Palm Oil Industry: A Critical Analysis. Presentation at ISEAS Workshop on the Oil Palm Controversy in Transnational Perspective. Singapore (SG): Institute of Southeast Asian Studies.

[18] Kebede. 2001. Tools to Support Participatory Urban Decision Making, UNCHS Habitat, Nairobi

[19] Murphy, Denis. J. 2014. The Future of Oil Palm as A Major Global Crop: Opportunities and Challanges. Journal of Oil Palm Research Vol.26 (1). United Kingdom.

[20] Pearce II JA, Robinson Jr RB. 1998. Strategic Management. Illinois: Richard D. Irwin Inc.

[21] Rastogi A, Badola R, Hussain SA, Hickey GM. 2010. Assessing the utility of stakeholder analysis to protected areas management: the case of Corbett National Park, India. Biological Conservation.

[22] Saaty TL. 2008. Decision Making with The Analytic Hierarchy Process. Int. J. Servi. Sciences,

[23] Teoh CH. 2010. Key Sustainability Issues in the Palm Oil Sector. International Finance Corporation, World Bank Group.

[24] Thomson AA, Strickland AJ, Gamble JE. 2005. Crafting and Executing Strategy: The Quest for Competitive Advantage 14th edition. . New York (US): McGraw-Hill/Irwin.

[25] Van Gelder, J. W. 2004. Greasy Palms: European Buyers of Indonesian Palm Oil. 